\title{
ADENYLYLATION OF TROSPECTOMYCIN BY CRUDE ENZYME PREPARATIONS FROM ESCHERICHIA COLI
}

\author{
Y. Yagi, L. Baczynskyj, S. A. Mizsak and A. D. Argoudelis \\ The Upjohn Company, \\ Kalamazoo, Michigan 49001, U.S.A.
}

(Received for publication March 10, 1988)

\begin{abstract}
Employing osmotically shocked lysate of a spectinomycin resistant strain of Escherichia coli, trospectomycin, a new alkylspectinomycin, was adenylylated in the presence of adenosine $5^{\prime}$-triphosphate and magnesium ion. A highly resistant strain of $E$. coll was obtained by transforming a laboratory strain with a newly constructed plasmid consisting of pBR322 and a determinant for spectinomycin resistance originally found on a low cony number plasmid in E. coli strain NR79. The biologically inactive adenylylated trospectomycin was found to be trospectomycin 6-(5'-adenylate).
\end{abstract}

Trospectomycin (U-63366; Fig. 1, 1a) is a new alkylspectinomycin analog described by WHITE and his co-workers. ${ }^{1)}$ Recent in vitro studies indicate that trospectomycin is more effective than spectinomycin against various organisms ${ }^{2)}$ including Haemophilus ducreyi, ${ }^{3)}$ penicillin-resistant strains of Neisseria gonorrohoeae ${ }^{2)}$ and Chlamydia trachomatis (abstract: G. E. Zurenko et al., 2nd World Cong. on Sexually Transmitted Dis., Paris, 1986; abstract: E. Novak et al., 15th Int. Cong. of Chemother., Istanbul, 1987). It has also been shown that pretreatment of a strain of $E$. coli with trospectomycin enhances ability of serum to kill the organism.4) In the past, enzymatic inactivation has been reported on various antibiotics such as spectinomycin (Fig. 1, 1b), lincomycin and clindamycin.. ${ }^{5 \sim 7}$ In case of spectinomycin, inactivation has been accomplished by an adenylylating enzyme

Fig. 1. Structures of trospectomycin 6-(5'-adenylate), trospectomycin and spectinomycin.

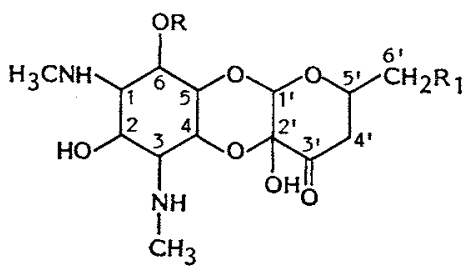

Trospectomycin 6-(5'-adenylate) (1) $\mathrm{R}=$<smiles></smiles>

$$
\mathrm{R}_{1}=\stackrel{7}{\mathrm{C}} \mathrm{H}_{2} \stackrel{\mathrm{C}^{\prime}}{\mathrm{C}} \mathrm{H}_{2} \stackrel{9^{\prime}}{\mathrm{C}} \mathrm{H}_{3}
$$

Trospectomycin (1a) $\mathrm{R}=\mathrm{H} \quad \mathrm{R}_{1}=\mathrm{CH}_{2} \mathrm{CH}_{2} \mathrm{CH}_{3}$

Spectinomycin (1b) $\mathbf{R}=\mathbf{H} \mathbf{R}_{1}=\mathrm{H}$ 
Table 1. Strains.

\begin{tabular}{|c|c|c|c|c|}
\hline & UC a I.D. & $\begin{array}{c}\text { Additional strain } \\
\text { designation }\end{array}$ & Plasmid $^{\mathrm{b}}$ & Reference \\
\hline Escherichia coli & UC 3833 & NR79 & pUC18 & 6 \\
\hline E. coli & UC 9224 & MC 1061 & None & 12 \\
\hline E. coli & UC 9464 & MC 1061 (pUC18) & pUC18 & This study \\
\hline E. coli & UC 12150 & MC 1061 (pUC1153) & pUC1153 & This study \\
\hline
\end{tabular}

a Upjohn Company culture collection.

b The designation "pUC" has been assigned to The Upjohn Company by Plasmid Reference Center (Stanford, CA, U.S.A.).

which acts on the hydroxyl group at the C-6 position of the actinamine moiety (Fig. $1,1 \mathrm{~b}$ ). ${ }^{7}$ In this report we present data indicating that trospectomycin (1a) is adenylylated by a cell-free extract of an E. coli strain which harbors a recombinant plasmid to direct overproduction of an adenylylating enzyme, and that the product of adenylylation is trospectomycin 6-(5'adenylate) (Fig. 1, 1).

\section{Materials and Methods}

Bacterial Strain

$E$. coli strains used in this study are listed in Table 1. The plasmid pUC18 (Fig. 2), found in E. coli NR79, UC 3833, was transformed into E. coli MC 1061, UC 9224, to generate E. coli UC 9464. Gene

Sub-cloning of Spectinomycin-resistance

Standard protocols were used for isolation of plasmids ( $\mathrm{pUC18}, \mathrm{pBR} 322$ ) from SDS lysates by ultracentrifugation and subsequent cloning of the spectinomycin-resistance gene of pUC18 into pBR322. ${ }^{8)}$ Selection for spectinomycin-resistant clones was carried out employing antibiotic medium No. 3 (Difco) with $100 \mu \mathrm{g}$ of spectinomycin per $\mathrm{ml}$. The enzymes necessary for molecular cloning were obtained from New England Biolabs (Beverly, MA, U.S.A.).

Determination of Antibiotic Resistance

The MIC was determined by the established tube dilution method employing the 0.5 McFarland turbidity standard. ${ }^{\text {) }}$
Fig. 2. Agarose gel $(0.6 \%)$ electrophoresis of plasmid preparations.

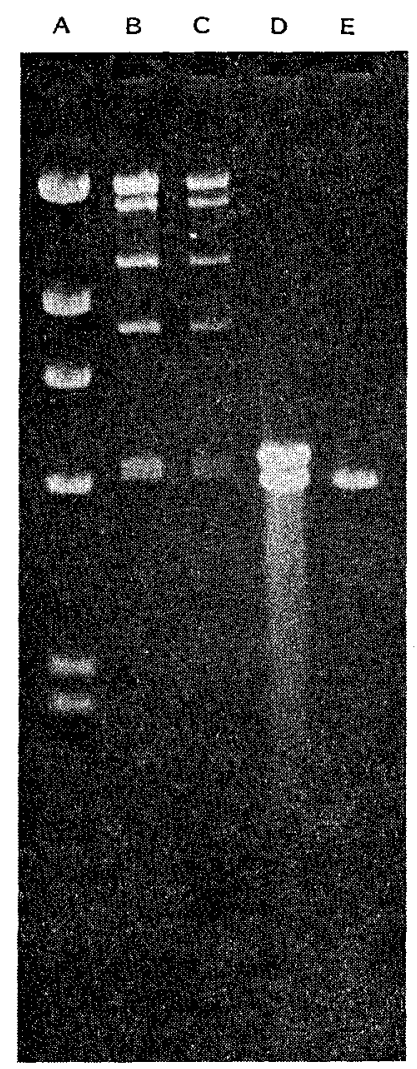

A, phage $\lambda$ digested by Hind III; B, pUC18 from strain UC 3833; C, pUC18 from strain UC 9464; D, pUC1153 from strain UC 12150; E, pBR322, $(\mathrm{B} \sim \mathrm{E}$, digested by $\mathrm{Bam} \mathrm{H} \mathrm{I})$.

Media

The modified medium B of Nossal and HEPPEL ${ }^{10)}$ was employed. For the MIC determination, Mueller-Hinton broth (Difco) was used. 
Inactivation of Trospectomycin by Cell-free Extracts

The cells ( $E$. coli, UC 12150) were grown to late logarithmic phase in $100 \mathrm{ml}$ of the medium described above. After washing twice in $20 \mathrm{ml}$ of TS buffer $(0.03 \mathrm{M} \mathrm{NaCl}, 0.01 \mathrm{M}$ Tris, pH 7.0) the cells were resuspended in $60 \mathrm{ml}$ of STE buffer $\left(20 \%\right.$ sucrose, $1 \times 10^{-3} \mathrm{M}$ EDTA, $3.3 \times 10^{-2} \mathrm{M}$ Tris, pH 7.1$)$ and stirred at room temperature for 40 minutes. This was then centrifuged $\left(13,000 \times g, 0^{\circ} \mathrm{C}, 10\right.$ minutes) to obtain a cell pellet, which was resuspended and stirred in $7.5 \mathrm{ml}$ of ice cold distilled water for 25 minutes. Finally it was centrifuged $\left(13,000 \times g, 0^{\circ} \mathrm{C}, 20\right.$ minutes) to obtain clear supernatant (shockate), which represented a crude enzyme preparation. Protein in the shockate was quantitated by a Bio-Rad protein assay kit. For a larger scale inactivation of trospectomycin, a 4-liter culture was processed accordingly. Inactivation of trospectomycin was carried out (at $37^{\circ} \mathrm{C}, 11$ hours) by mixing $125 \mu \mathrm{l}$ of Tris-acetate buffer $(0.5 \mathrm{M}, \mathrm{pH} 7.1), 75 \mu \mathrm{l}$ of magnesium acetate (20 mM, pH 7.1), $50 \mu \mathrm{l}$ of ATP $(0.1 \mathrm{M})$, appropriate amount of the cell-free extract, trospectomycin (in water) and distilled water to make up a final volume of $500 \mu l$.

\section{Enzymatic Hydrolysis}

Seven $\mu \mathrm{g}$ of inactivated trospectomycin was treated with $136 \mu \mathrm{g}$ of venom phosphodiesterase (Worthington Biochemical) and $70 \mu \mathrm{l}$ of buffer solution consisting of $0.05 \mathrm{M}$ glycine $-\mathrm{NaOH}$ buffer

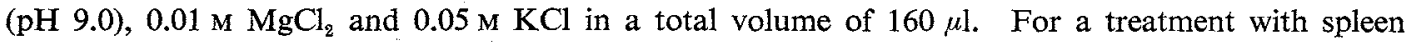
phosphodiesterase (Worthington Biochemical) $300 \mu \mathrm{g}$ of inactivated trospectomycin was mixed with $0.6 \mathrm{U}$ of the enzyme and $100 \mu \mathrm{l}$ of $0.25 \mathrm{M}$ sodium succinate $-\mathrm{HCl}$ buffer (pH 6.5) in a total volume of $600 \mu \mathrm{l}$. In both cases the reaction mixtures were incubated at $37^{\circ} \mathrm{C}$ for 16 hours.

\section{Spectroscopic Methods}

${ }^{1} \mathrm{H}$ NMR spectra were recorded on a Varian XL-200 spectrometer operating at $100 \mathrm{MHz}$. Spectra were run in $\mathrm{D}_{2} \mathrm{O}$ using sodium 2,2-dimethyl-2-silapentane-5-sulfonate (SDSS) as internal reference. ${ }^{13} \mathrm{C}$ NMR spectra were recorded on a Varian XL-200 spectrometer operating at $50.3 \mathrm{MHz} . \mathrm{D}_{2} \mathrm{O}$ was used as the solvent. ${ }^{1} \mathrm{H}$ and ${ }^{13} \mathrm{C}$ NMR chemical shifts are reported as ppm relative to TMS. IR spectra were obtained in mineral oil suspension on a Digilab Model 14D Fourier Transform Spectrometer. Fast atom bombardment (FAB) spectra were obtained on a VG-ZAB-2F mass spectrometer.

\section{Assay of Trospectomycin and Trospectomycin 6-(5'-Adenylate)}

Since trospectomycin 6-(5'-adenylate) lacks in vitro antibacterial activity, its formation from trospectomycin can be followed by measuring the loss of its antibacterial activity. To determine the amount of trospectomycin in reaction mixtures or preparations obtained during purification a standard assay using either $E$. coli UC 51 or Bacillus subtilis UC 564 was employed. To assay for the presence of trospectomycin 6-(5'-adenylate), the phosphodiester bond was first hydrolyzed using snake venom phosphodiesterase by the procedure described above. The amount of trospectomycin in the hydrolysate was determined by a standard assay method.

\section{TLC Analysis}

The production and purification of trospectomycin 6-(5'-adenylate) were followed by TLC using Silica gel GF plates (Analtech) and water as the mobile phase. UV absorbing materials were detected by a short wavelength UV lamp. Bioinactive, UV-nonabsorbing materials were detected by permanganate-periodate spray reagent. Bioactive materials (trospectomycin) were detected by bioautography on agar seeded with $E$. coli UC 51. Trospectomycin 6-(5'-adenylate) exhibited an Rf value of 0.4 in this TLC system.

\section{Isolation and Purification of Trospectomycin 6-(5'-Adenylate)}

A reaction mixture containing approximately $500 \mathrm{mg}$ of inactivated trospectomycin was adjusted to pH 7.5 and passed over a column containing $100 \mathrm{ml}$ of Amberlite XAD-2 (Rohm and Haas Co., Philadelphia, PA). The spent was collected as one fraction. The column was washed with $300 \mathrm{ml}$ of water and eluted with $\mathrm{MeOH}$ - water $(70: 30)$. The reaction mixture and the fractions obtained during the chromatography were analyzed for bioactivity before and after treatment with snake venom phosphodiesterase by UV determination at $260 \mathrm{~nm}$ as well as by TLC. Results indicated that the 
starting material contained ATP, ADP, AMP and trospectomycin 6-(5'-adenylate); spent and aqueous wash contained mainly the different adenosine phosphates, while the methanolic eluates contained all of trospectomycin 6-(5'-adenylate) present in the reaction mixture. The methanolic eluates were combined and concentrated to an aqueous solution which was then freeze-dried to yield approximately $450 \mathrm{mg}$ of a colorless material; UV $\lambda_{\max } \mathrm{nm}(a), 260$ (18.5). TLC on this preparation showed the presence of trospectomycin 6-(5'-adenylate) and trace of adenosine phosphates (ATP, ADP, AMP).

\section{Isolation of Pure Trospectomycin 6-(5'-Adenylate)}

A column was prepared from $200 \mathrm{ml}$ of Amberlite XAD-2 in water. The starting material, $450 \mathrm{mg}$ of the material isolated as described above, was dissolved in $20 \mathrm{ml}$ of $0.1 \mathrm{M}$ phosphate buffer (pH 7.0). This solution was passed over the column at a rate of $2 \mathrm{ml}$ per minute. The column was washed with $600 \mathrm{ml}$ of water, then with $\mathrm{MeOH}$ - water $(10: 90), 600 \mathrm{ml}$; $\mathrm{MeOH}$ - water $(30: 70)$, $600 \mathrm{ml}$; $\mathrm{MeOH}$ - water $(50: 50), 600 \mathrm{ml}$; finally $\mathrm{MeOH}$ - water $(70: 30), 600 \mathrm{ml}$. Fractions containing trospectomycin 6-(5'-adenylate) were combined, concentrated in an aqueous solution and freezedried to give $330 \mathrm{mg}$ of pure trospectomycin 6-(5'-adenylate).

Anal Calcd for $\mathrm{C}_{27} \mathrm{H}_{42} \mathrm{~N}_{7} \mathrm{O}_{13} \mathrm{P} \cdot \mathrm{H}_{2} \mathrm{O}$ (MW 721): C 44.93, $\mathrm{H}$ 6.10, N 13.59, P 4.30. Found C $45.07, \mathrm{H} 5.62, \mathrm{~N} 13.18, \mathrm{P} 3.69$.

MW (FAB), $722\left(\mathrm{M}+\mathrm{H}^{+}+\mathrm{H}_{2} \mathrm{O}\right), 704\left(\mathrm{M}+\mathrm{H}^{+}\right)$. Further characterization of trospectomycin 6-(5'-adenylate $)$ is described in the following sections.

\section{Results and Discussion}

\section{Subcloning a Spectinomycin-resistance Gene into pBR322}

A spectinomycin adenylylating enzyme has previously been isolated from an E. coli strain NR73/

Fig. 3. Construction and a restriction map of pUC 1153.
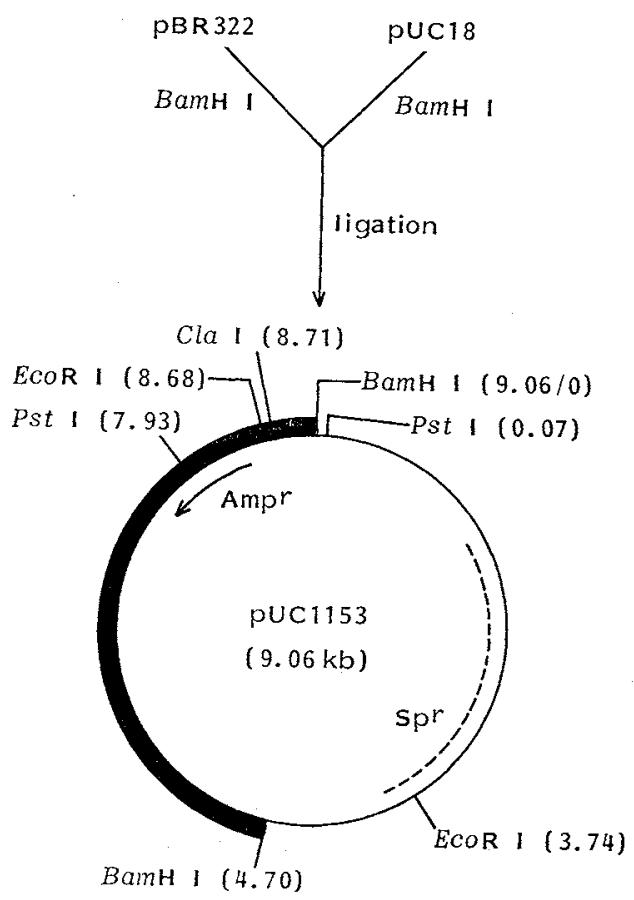

PBR 322
W677 which is phenotypically similar to the original parent strain (NR79/W677) used in this study. ${ }^{6)}$ The initial examination revealed that the plasmid, pUC18, in NR79 exists as a low copy number molecule with molecular size of approximately $90 \mathrm{~kb}$ (Fig. 2). In order to facilitate large scale adenylylation of trospectomycin by a cell-free extract of a spectinomycin-resistant strain of E. coli, we attempted to subclone the spectinomycin-resistance gene into a high copy number plasmid pBR322. We hoped that either a high copy number of the gene or a more efficient promoter on pBR322 would result in better production of the adenylylating enzyme.

Table 2. MICs of drugs against Escherichia coli strains.

\begin{tabular}{lrc}
\hline Strain & $\begin{array}{c}\text { Spectino- } \\
\text { mycin } \\
(\mu \mathrm{g} / \mathrm{ml})\end{array}$ & $\begin{array}{c}\text { Trospecto- } \\
\text { mycin } \\
(\mu \mathrm{g} / \mathrm{ml})\end{array}$ \\
\hline MC 1061, UC 9224 & 20 & 10 \\
NR79, UC 3833 & 640 & 320 \\
MC 1061 (pUC18), & 1,280 & 320 \\
UC 9464 & & \\
MC 1061 (pUC1153), & $>2,560$ & 1,280 \\
UC 12150 & & \\
\hline
\end{tabular}


Table 3. Requirements for inactivation of trospectomycin.

\begin{tabular}{lcccc}
\hline Reaction conditions & \multicolumn{4}{c}{ Trospectomycin $\left(\mu \mathrm{g} \times 10^{-1} \mathrm{ml}\right)$} \\
\cline { 2 - 4 } & 0 hour & 3 hours & 6 hours & 11 hours \\
\hline Complete mixture & 8.0 & 3.0 & 1.2 & 0 \\
Without ATP & 6.0 & 6.0 & 6.0 & 5.5 \\
Without $\mathrm{Mg}^{2+}$ & 6.0 & 6.0 & 5.5 & 5.5 \\
Without shockate & 6.0 & 6.0 & 6.0 & 5.0 \\
With heated shockate & 10.0 & $\mathrm{ND}$ & $\mathrm{ND}$ & 8.0 \\
$\left(65^{\circ} \mathrm{C}, 10\right.$ minutes $)$ & & & & \\
\hline
\end{tabular}

ND: Not determined.

As outlined in Fig. 3, the BamH I digested preparations of pUC18 and pBR322 were ligated, and the mixture was transformed into E. coli MC 1061. Among the spectinomycin-resistant transformants (selected on a plate containing $100 \mu \mathrm{g}$ of spectinomycin per ml), the isolate UC 12150 harbored a plasmid (designated pUC1153, Figs. 2 and 3) consisting of pBR322 and a $4.7-\mathrm{kb}$ insert. When the MICs of trospectomycin were compared among the E. coli strains (Table 2), it was found that the newly constructed strain UC 12150 was much more resistant to the drug (MIC $1,280 \mu \mathrm{g} / \mathrm{ml}$ ) than its isogenic parent UC 9464, which harbors the original low copy plasmid pUC18 (MIC $320 \mu \mathrm{g} / \mathrm{ml}$ ). Similar differences in the spectinomycin MICs were observed among those strains (Table 2).

Trospectomycin Inactivating Activity in the Osmotic Shockate of UC 12150

Cell-free extracts were prepared from osmotically shocked cells of UC 9464 and the highly resistant strain UC 12150 in order to determine their enzymatic activities to inactivate trospectomycin (Fig. 4). For total inactivation of $50 \mu \mathrm{g}$ of trospectomycin in 11 hours $20 \mu \mathrm{l}$ (corresponding to osmotic shockate protein concentration of $108 \mu \mathrm{g} / \mathrm{ml}$ ) of the high producer UC 12150 shockate was required

Fig. 4. Inactivation of trospectomycin by cell-free extracts of Escherichia coli UC 12150 (-) and UC $9464(\square)$.

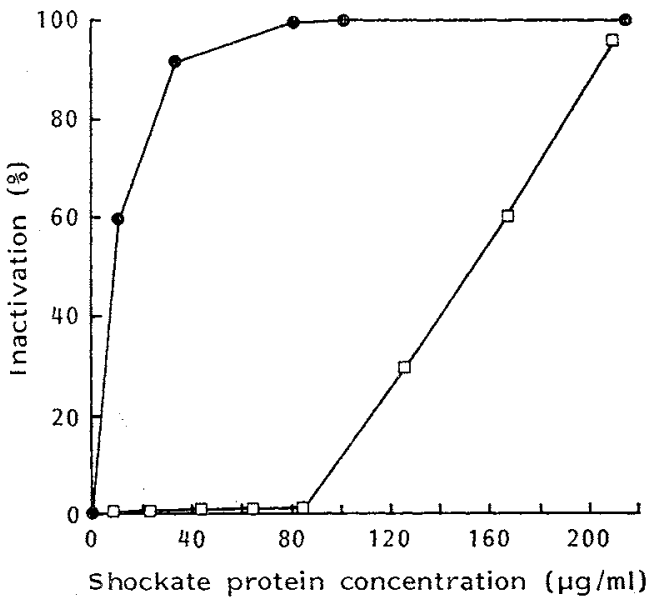

A total of $50 \mu \mathrm{g}$ of trospectomycin was treated by various amounts of the shockate preparations as described in Materials and Methods. Inactivation was measured on Bacillus subtilis UC 564 as an assay organism. in a total volume of $500 \mu \mathrm{l}$ of the reaction mixture. On the other hand it took $50 \mu 1$ (corresponding to $210 \mu \mathrm{g} / \mathrm{ml}$ of the shockate protein) of the osmotic shockate prepared from the isogenic parent strain UC 9464 in order to inactivate $96 \%$ of the same amount of trospectomycin. As indicated by the results in

Table 4. Reactivation of trospectomycin 6-(5'adenylate).

\begin{tabular}{cccc}
\hline Enzyme & & $\begin{array}{c}\text { Bacillus subtilis } \\
\text { growth inhibition } \\
\text { (mm zone) }\end{array}$ \\
\cline { 2 - 4 } Senom phosphodiesterase & + & 0 & 26 \\
& - & 0 & 0 \\
Spleen phosphodiesterase & + & 0 & 0 \\
& $-\cdots$ & 0 & 0 \\
\hline
\end{tabular}

At the time indicated $75 \mu 1$ of the reaction mixture was spotted on a $1.25-\mathrm{cm}$ (diameter) filter disc, which was then placed on an agar-medium seeded with $B$. subtilis UC 564. A zone of inhibition was read after overnight incuhation at $37^{\circ} \mathrm{C}$. 
Table 3, inactivation of trospectomycin requires ATP, $\mathrm{MgCl}_{2}$, and cell-free extract of $E$. coli $\mathrm{UC} 12150$. The inactivated trospectomycin was slowly reactivated by venom phosphodiesterase but not by spleen phosphodiesterase indicating linkage between $5^{\prime}$-P of ATP and trospectomycin (Table 4).

\section{Production and Isolation of Trospectomycin 6-(5'-Adenylate)}

A crude enzyme preparation was used to adenylylate $500 \mathrm{mg}$ of trospectomycin as described in Materials and Methods. Since trospectomycin adenylate lacks in vitro antibacterial activity, its formation from trospectomycin was followed by measuring the loss of such antibacterial activity using $E$. coli UC 51 as the assay organism. Incubation of the reaction mixture for 15 hours $\left(37^{\circ} \mathrm{C}\right)$ resulted in sufficient inactivation of trospectomycin and its transformation to a UV-absorbing material, which

Fig. 5. FAB-MS of trospectomycin 6-(5'-adenylate).

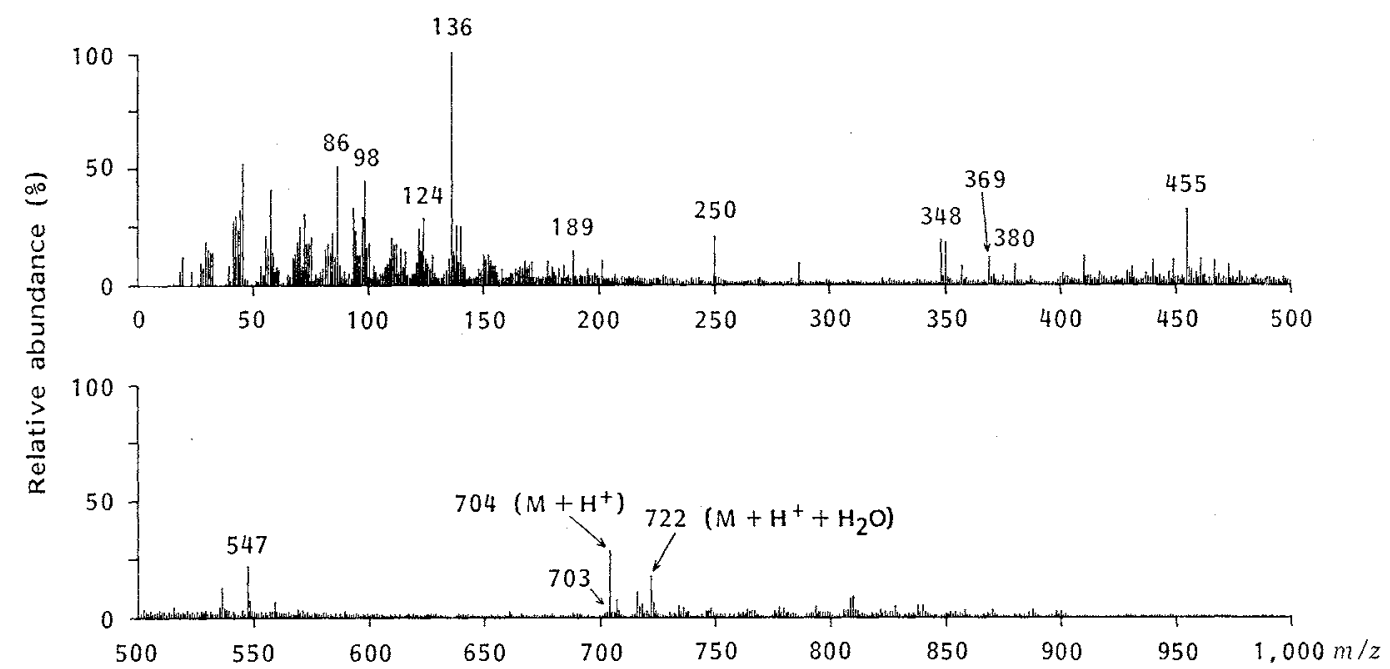

Fig. 6. IR spectrum of trospectomycin 6-(5'-adenylate).

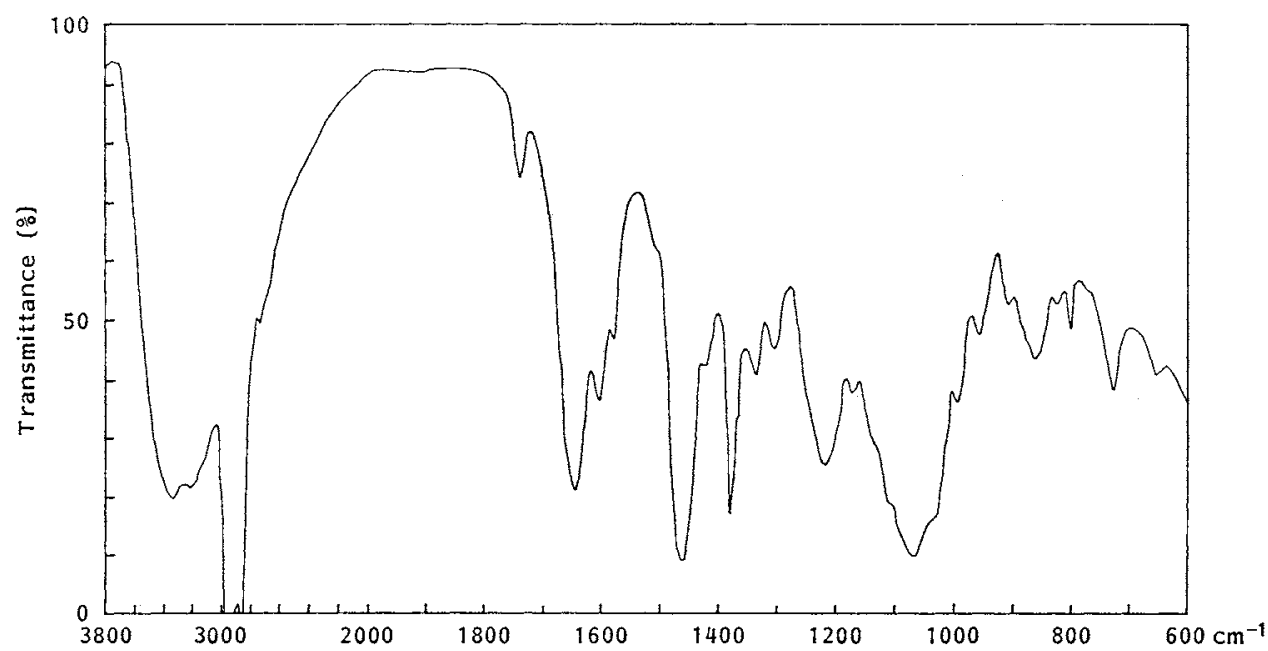


yielded trospectomycin upon treatment with snake venom phosphodiesterase. Isolation and purification of trospectomycin adenylate were followed by TLC, UV absorption at $260 \mathrm{~nm}$ and in vitro assays before and after treatment with snake venom phosphodiesterase. Pure, "inactivated" trospectomycin was isolated from the reaction mixture by repeated chromatographies on Amberlite XAD-2 as described in detail in the Materials and Methods. Trospectomycin adenylate was eluted with methanol - water (30:70 to 50:50) and isolated as an amorphous colorless powder. TLC of this material showed the presence of only one compound.

\section{Characterization and Structure of Trospectomycin Adenylate}

Trospectomycin adenylate was isolated as an amorphous colorless material soluble in water and lower alcohols and practically insoluble in acetone as well as ethyl acetate. Analytical data combined with molecular weight determination by negative ion FAB-MS (Fig. 5 and Table 5) indicated the molecular formula of $\mathrm{C}_{27} \mathrm{H}_{42} \mathrm{NO}_{13} \mathrm{P} \cdot \mathrm{H}_{2} \mathrm{O}$; MW 703 and 721 (hydrated form). The IR spectrum (Fig. 6) showed weak carbonyl absorption at $1738 \mathrm{~cm}^{-1}$ indicating the presence of some trospectomycin adenylate in the nonhydrated form. The UV spectrum showed a maximum at $258 \mathrm{~nm}$ ( $a=17.27, E=12,150$ ) supporting the presence of an adenosine moiety in the molecule of inactivated trospectomycin. The molecular formula (specifically the presence of one $\mathbf{P}$ atom per molecule) and the conversion of trospectomycin adenylate to trospectomycin by treatment with snake venom phosphodiesterase (but not with spleen phosphodiesterase) indicated that inactivated trospectomycin has a

Fig. 7. ${ }^{1} \mathrm{H}$ NMR (A) and ${ }^{13} \mathrm{C}$ NMR (B) spectra of trospectomycin 6-(5'-adenylate).

(A)

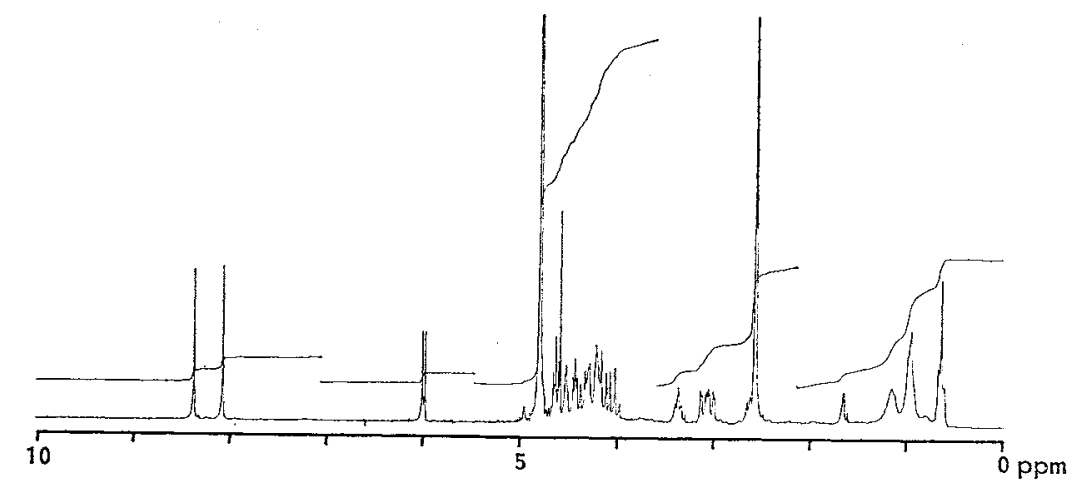

(B)

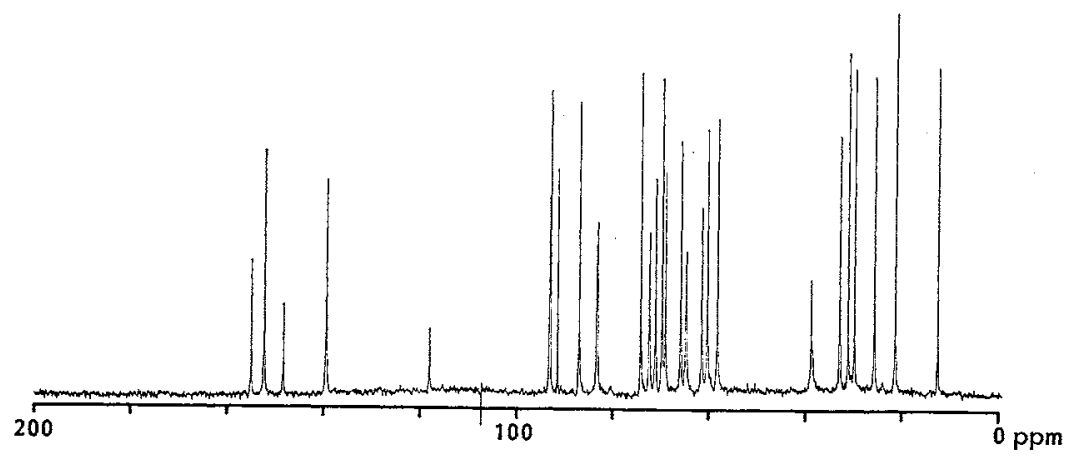


Fig. 8. Fragments observed in the high resolution-FAB-MS of trospectomycin 6-(5'-adenylate).<smiles>CCCCC1CC(=O)C2(O)OC3C(NC)C(O)C(NC)C(OP(=O)(O)O)C3OC2O1</smiles>

2

$455 \mathrm{C}_{17} \mathrm{H}_{30} \mathrm{~N}_{2} \mathrm{O}_{10} \mathrm{P}+\mathrm{H}_{2}$

455.1794

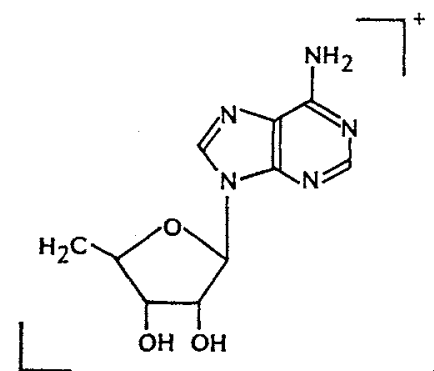

3

$250 \mathrm{C}_{10} \mathrm{H}_{12} \mathrm{~N}_{5} \mathrm{O}_{3}$

250.0940

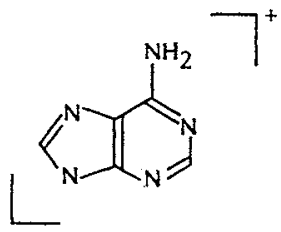

4

$136 \mathrm{C}_{5} \mathrm{H}_{4} \mathrm{~N}_{5}+\mathrm{H}_{2}$

136.0623

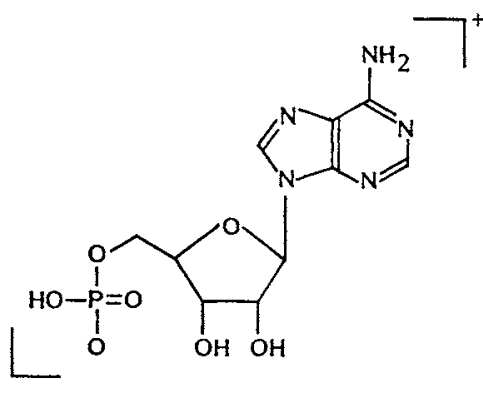

5

$348 \mathrm{C}_{10} \mathrm{H}_{13} \mathrm{~N}_{5} \mathrm{O}_{7} \mathrm{P}+\mathrm{H}_{2}$ 348.0709

structure in which trospectomycin is linked to the phosphate group of adenosine-5'-phosphate. This is in agreement with the potentiometric titration $(\mathrm{KOH}, 80 \%$ aq ethanol) results which showed the presence of an acidic group in trospectomycin adenylate. The assignment of the phosphate diester linkage at the C-6 position of the actinamine moiety of trospectomycin (Fig. 1) is based on comparison of ${ }^{18} \mathrm{C}$ NMR spectra of trospectomycin and trospectomycin adenylate (Fig. 7 and Table 5). As shown in Table 5, there is an excellent agreement between the chemical shifts of 16 of the carbons of trospectomycin and the corresponding carbons of the adenylate. The chemical shift of the remaining carbon (C-6) of trospectomycin appears at $\delta 64.9$ while C-6 of trospectomycin adenylate has a chemical shift of $\delta$ 72.9. This is due to the deshielding effect of the phosphate group attached at C- 6 of trospectomycin adenylate. ${ }^{11)}$ Furthermore, the chemical shifts of the carbons of ribose and adenine moieties of trospectomycin adenylate are almost identical to those of adenosine 5 '-phosphate (Table 5). It should be noted that the chemical shifts of C-5 of ribose in adenosine 5 -phosphate $(\delta$ 64.4) and trospectomycin 6-(5'-adenylate) ( $\delta 65.3)$ are higher than the chemical shifts of $\mathrm{C}-5$ of adenosine $(\delta 61.9)$. This is also due to the deshielding effect of the phosphate group at C-5 of ribose. 
We, therefore, conclude that ${ }^{13} \mathrm{C}$ NMR also indicates a phosphodiester bond between $\mathrm{C}-6$ of trospectomycin and C-5 of the ribose moiety of adenosine as shown in Fig. 1, 1. The ${ }^{1} \mathrm{H}$ NMR spectrum (Fig. 7) indicates the presence of 11 protons in the area of $\delta 0.6$ to 1.7 assigned to the $\mathrm{CCH}_{3}$ and the four $\mathrm{CH}_{2}$ groups of trospectomycin 6-(5'-adenylate). Absorptions due to the two $\mathrm{NCH}_{3}$ groups are present at ca. $\delta 2.58$. Also complex absorptions due to the $\mathrm{CHO}$ and $\mathrm{CHN}$ of the remaining of the adenylate molecule are present at $\delta 3.0$ to 4.8 . The anomeric proton of adenosine appears at $\delta 6.02(1 \mathrm{H}$, doublet), and the two "aromatic" protons of adenine appear at $c a . \delta 8.15$ and 8.43 as singlets. The fragmentation pattern obtained in the FAB spectrum of the adenylate (Fig. 8) is also in agreement with the conclusion that $\mathbf{1}$ (Fig. 1) is the structure of trospectomycin adenylate.

Biological Properties of Trospectomycin

$$
\text { 6-(5'-Adenylate) }
$$

Trospectomycin 6-(5'-adenylate) is bioinactive in vitro. In vitro treatment with venom phosphodiesterase slowly transforms the adenylate to trospectomycin which inhibits the growth of both Gram-positive (Table 4) and Gramnegative bacteria. ${ }^{12)}$ When, however, trospectomycin 6-(5'-adenylate) was administered subcutaneously at $30 \mathrm{mg} / \mathrm{kg}$, it did not protect mice infected with Streptococcus pyogenes indicating that in vivo enzymatic transformation of the ribonucleotide prodrug 1 (Fig. 1) to its active form 1a (Fig. 1) occurs slowly (if at all). (The $\mathrm{CD}_{50}$ of trospectomycin in the same system was $c a .3 .0 \mathrm{mg} / \mathrm{kg}$.)

\section{Acknowledgments}

The authors express their appreciation to Dr. D. R. WHITE for providing trospectomycin, Dr. C. W. FORD for the in vivo study, and Mr. K. J. GEIPEL for technical assistance.

\section{References}

1) White, D. R.; C. J. Maring \& G. A. Cain: Synthesis and in vitro antibacterial properties of alkylspectinomycin analogs. J. Antibiotics 36: 339 342, 1983

2) Zurenko, G. E.; B. H. YaGi, J. J. VAVRa \& B. B. Wentworth: In vitro antibacterial activity of trospec-

t The ${ }^{31} \mathrm{P}^{13} \mathrm{C}$ coupling constants $(\mathrm{Hz})$ observed were as follows: $J_{\mathrm{P}-\mathrm{C}-5}$ (ribose) $4.4 ; J_{\mathrm{P}-\mathrm{C}-4}$ (ribose) $9.2 ; J_{\mathrm{P}-\mathrm{C}-6}$ trospectomycin 6-(5'-adenylate) $6.1 ; J_{\mathrm{P}-\mathrm{C}-1}$ trospectomycin 6-(5'-adenylate) 3.3 . 
tomycin (U-63366F), a novel spectinomycin analog. Antimicrob. Agents Chemother. 32: 216 223, 1988

3) Sanson-LePors, M.-J.; I. M. Casin, M.-C. Thebault, G. Arlet \& Y. Perol: In vitro activities of U63366 , a spectinomycin analog; roxithromycin (RU 28965), a new macrolide antibiotic; and five quinolone derivatives against Haemophilus ducreyi. Antimicrob. Agents Chemother. 30: 512 513, 1986

4) Claldella, J. I.; J. J. Vavra \& V. P. Marshall: Susceptibility of bacteria to serum lysis or phagocytosis following growth in subinhibitory levels of lincosaminide or spectinomycin related antibiotics. J. Antibiotics 39: 978 984, 1986

5) Marshall, V.P.; T. E. Patt \& A. D. Argoudelis: Enzymatic nucleotidylylation of lincosaminide antibiotics. J. Ind. Microbiol. 1: 17 21, 1986

6) Benveniste, R.; T. Yamada \& J. Davies: Enzymatic adenylation of streptomycin and spectinomycin by R-factor-resistant Escherichia coli. Infec. Immun. 1: 109 119, 1970

7) Shimizu, S.; M. Inoue, S. Mitsuhashi, H. Naganawa \& S. Kondo: Enzymatic adenylylation of spectinomycin by Acinetobacter calcoaceticus subsp. anitratus. J. Antibiotics 34: 869 875, 1981

8) Maniatis, T.; E. F. Fritsch \& J. Sambrook: Molecular Cloning (A Laboratory Manual). Cold Spring Harbor Laboratory, Cold Spring Harbar, New York, 1982

9) ThornsBerry, C. $(E d$.): Methods for Dilution Antimicrobial Susceptibility Tests for Bacteria that Grow Aerobically (Approved Standard M7-A). National Committee for Clinical Laboratory Standards, Villanova, 1985

10) Nossal, N. G. \& L. A. Heppel: The release of enzymes by osmotic shock from Escherichia coli in exponential phase. J. Biol. Chem. 241: 3055 3062, 1966

11) Stothers, J. B. (Ed.): Carbon-13 NMR Spectroscopy. pp. 469, 471, Academic Press, New York, 1972

12) Casadaban, M. J. \& S. N. Cohen: Analysis of gene control signals by DNA fusion and cloning in Escherichia coli. J. Mol. Biol. 138: 179 207, 1980 